\title{
UPAYA PENANGGULANGAN PENGANIAYAAN GURU
}

\section{Sugianto}

\section{Fakultas Hukum Universitas Kapuas Sintang Jalan Oevang Oeray 92 Sintang \\ Email : cosmas_sugianto@yahoo.com}

Abstract

Efforts to tackle criminal abuse committed by parents of students against teachers that occur in schools both at the high school, junior high school and elementary school level. This aims to determine the efforts made by the school to tackle teacher maltreatment and to find out the factors that cause teacher maltreatment by parents of students, and to find out whether a new law is needed to provide protection for teachers and lecturers.

Keywords: Efforts, Countermeasures, Persecution, Teachers.

\begin{abstract}
Abstrak
Upaya penanggulangan pidana penganiayaan yang dilakukan oleh orang tua murid terhadap guru yang terjadi di sekolah-sekolah baik ditingkat SMA, SMP dan SD. ini bertujuan untuk mengetahui Upaya-upaya yang dilakukan oleh sekolah untuk menanggulangi penganiayaan terhadap guru dan untuk mengetahui faktor-faktor penyebab terjadinya penganiayaan kepada guru yang dilakukan oleh orang tua murid, serta
\end{abstract}

mengetahui apakah diperlukan sebuah undang-undang baru untuk memberikan perlindungan bagi guru dan dosen.

Kata kunci : $\quad$ Upaya, Penanggulangan,Penganiayaan,Guru.

\section{Pendahuluan}

Sebagian besar masyarakat menganggap bahwa dunia pendidikan merupakan dunia yang sarat akan nilai-nilai kebaikan (etika) dan nilainilai keindahan (estetika), bahkan secara ekstrem disebut sebagai dunia tanpa cela, karena dunia pendidikan merupakan dunia untuk mewujudkan manusia lebih tangguh, bermartabat dan bermoral, sehingga manusia akan dapat survive dalam mengatasi masalah-masalah dalam hidupnya. Akan tetapi, benarkah anggapan semacam itu masih tetap eksis dalam dunia pendidikan di tengahtengah dunia yang serba berubah?

Kenyataan di masyarakat demikian bertolak belakang. Anggapan-anggapan tersebut telah mengalami pergeseran-pergeseran yang cukup signifikan seiring dengan dinamika masyarakat. Dunia pendidikan bukanlah dunia yang bebas dari masalah, bukan juga dunia yang tanpa cela. Sebaliknya, dunia pendidikan 
dewasa ini penuh dengan kompleksitas masalah, baik masalah internal dalam penyelenggaraan pendidikan itu sendiri, maupun masalah eksternal, sehingga dapat menghambat tujuan pendidikan yang ingin dicapai.

Di Indonesia sendiri, masalah dalam dunia pendidikan menempati posisi ketiga dari tiga masalah besar yang memerlukan penanganan yang serius dari pemerintah, yaitu:35

1. national security of national life and development;

2. equitable welfare of the people;

3. education as a crusial component of human resource development.

Masalah pendidikan di Indonesia tidak hanya berkisar pada masalah-masalah yang berada dalam ranah sosial ekonomi saja, tetapi juga masalah-masalah yang berada dalam ranah hukum. Adapun masalah pendidikan dalam ranah sosial ekonomi yang biasa terjadi adalah minimnya anggaran pendidikan, biaya pendidikan yang mahal, kurangnya tenaga profesional guru/tenaga pendidik, rendahnya kesejahteraan guru/tenaga pendidikan, kurangnya sarana dan prasarana pendidikan, manajemen pendidikan yang kacau, dan komersialisasi pendidikan. Masalah pendidikan dalam ranah hukum dapat berupa berbagai bentuk penyimpangan pendidikan yang mempunyai dampak yuridis tertentu.

Mengingat pendidikan merupakan salah satuinstrumenpokokbagisustainabledevelopment (pembangunan berkelanjutan) dari suatu negara, dan mengingat penyimpangan terhadap dunia pendidikan bukan hanya pelanggaran etika belaka, namun dapat dimungkinkan sebagai pelanggaran hukum dengan dampak yang ditimbulkan cukup signifikan, maka eksistensi hukum pidana diperlukan guna menanggulangi atau meminimalisasi terjadinya berbagai bentuk penyimpangan yang dapat merusak citra Pendidikan Nasional.

Guru merupakan bagian yang tak terpisahkan dari sistem pendidikan nasional kita saat ini oleh sebab itu pekerjaan menjadi guru sangat mulia dimana sering disebut Guru pahlawan tanpa tanda jasa. Guru memiliki kewajiban untuk mencerdaskan kehidupan Bangsa yang saat ini masih tertinggal dari segi moral dengan demikian guru diberi tugas seperti mendidik, mengajar, dan membina anak murid baik dari tingkat TK, SD, SMP, dan SMA yang berjasa untuk menentaskan kemiskinan dan kebodohan dari seluruh lini kehidupan demi memperjuangkan kesejahteraan pada setiap sendi - sendi kehidupan,

Di Indonesia, tanggung jawab negara akan penyelenggaraan pendidikan yang berkualitas bagi setiap warga negaranya secara eksplisit diatur dalam pembukaan Undang- Undang Dasar 1945, alinea keempat dan batang tubuh Pasal

31. Dalam pembukaan Undang-Undang Dasar 1945 alinea 4 menyatakan tujuan nasional negara Indonesia salah satunya adalah “.....Mencerdaskan 
kehidupan bangsa”36. Nampak dari pernyataan tersebut bahwa upaya mencerdaskan kehidupan bangsa hanya bisa dicapai melalui Pendidikan. Selanjutnya ditegaskan kembali dalam Pasal 31 ayat (1) Undang-Undang Dasar 1945, bahwa:37 "Tiap-tiap warga negara berhak mendapatkan pengajaran" dan, dalam Pasal 31 ayat (2)

dinyatakan bahwa : $38^{\text {" }}$ Pemerintah mengusahakan dan menyelenggarakan satu sistem pengajaran nasional yang diatur dalam satu sistem pengajaran nasional" "Guru adalah pendidik profesional dengan tugas utama mendidik, mengajar, membimbing, mengarahkan, melatih, menilai, dan mengevaluasi peserta didik pada pendidikan anak usia dini jalur pendidikan formal, pendidikan dasar, dan pendidikan menengah.

Dengan demikian bahwa guru adalah orang yang harus dihormati dan dihargai karenaa telah melatih, mendidik, membimbing, mengarahkan seseorang yang sebelumnya tidak pernah mengerti akan sesuatu ilmu pengetahuan dan setelah itu memiliki kemampuan yang setara si guru dan mendapatkan keabsahan yang sah untuk kehidupannya kelak.

Kemajuan teknologi dan informasi dewasa ini telah merusak generasi bangsa, perilaku yang tidak wajar tersebut sering kita dengar di televesi dan dibaca di majalah atau Koran dalam kurun

$36 \quad$ Alinea 4, Undang-Undang Dasar Negara Republik Indonesia 1945

$37 \quad$ Pasal 31 ayat (1) Undang-Undang Dasar Republik Indonesia 1945

$38 \quad$ Pasal 31 ayat (2) Undang-Undang Dasar Republik Indonesia 1945 waktu tiga tahun terakhir dimana pernah terjadi orang tua murid menampar seorang guru yang tidak bersalah. Penganiayan tersebut dilakukan oleh orang tua murid kepada guru dengan berbagai alasan yang baik karena anaknya dipukul, dicubit, dan dihukum, yang pada intinya keseluruhan tindakan guru tersebut merupakan bagian dari proses untuk mendidik si anak agar bisa seperti manusia Indonesia yang cerdas bagi keluarga dan Negara.

Berdasarkan pasal 39 ayat (3) guru mendapatkan Perlindungan hukum sebagaimana dimaksud pada ayat (2) mencakup perlindungan hukum terhadap tindak kekerasan, ancaman, perlakuan diskriminatif, intimidasi, atau perlakuan tidak adil dari pihak peserta didik, orang tua peserta didik, masyarakat, birokrasi, atau pihak lain. ${ }_{39}$ Perlindungan hukum terhadap guru yang dimaksud undang - undang diatas tidak disebutkan dengan jelas sehingga, sering para guru di sekolah mendapatkan ancaman dan kekerasan baik penganiayaan dari orang tua murid. Penganiayaan terhadap guru oleh orang tua murid merupakan perilaku yang termasuk tindak pidana sehingga prosedural hukumnya melalui Kitab Hukum Undang - Undang Hukum Pidana.

Menurut Barda Nawawi Arief mengenai upaya penanggulangan berbagai bentuk perilaku menyimpang adalah sebagai berikut:

$39 \quad$ Pasal 39 ayat (3) Undang - Undang Tentang Guru dan Dosen nomor 14 Tahun 2005 
"Bahwa upaya penanggulangan berbagai bentuk perilaku menyimpang dapat ditempuh melalui upaya non-penal dan upaya penal. Upaya nonpenal biasanya menitikberatkan pada upayaupaya yang sifatnya pencegahan (preventive) terhadap terjadinya kejahatan, dengan cara menangani faktor-faktor kondusif penyebab terjadinya kejahatan. Sedangkan, upaya penal merupakan upaya penanggulangan dengan menggunakan hukum pidana. Upaya penal ini menitikberatkan pada upaya-upaya yang sifatnya memberantas (repressive).40

Hoebel menyimpulkan 41 ada empat

fungsi dasar hukum :

1. Menetapkan hubungan - hubungan antra para anggota masyaraakat, dengan menunjukkan jenis - jenis tingkah laku-tingkah laku apa yang diperkenankan dan apa pula yang dilarang,

2. Menentukan pembagian kekuasaan dan merinci siapa saja yang boleh melakukan serta siapakah yang harus mentaatinya dan sekaligus memilihkan sanksi - sanksinya yang tepat dan efektif,

3. Menyelesaikan sengketa,

4. Memelihara kemampuan masyarkat untuk menyesuaikan diri dengan kondisi - kondisi kehidupan yang berubah, yaitu dengan cara

40 Barda Nawawi Arief, Bunga Rampai Kebijakan Hukum Pidana, PT. Citra Aditya Abadi, Bandung, 2002, hlm 42

$41 \quad$ Esmi Warassih, Pranata Hukum Sebuah Telaah Sosiologis, Pustaka Magister

Semarang, 2014, hlman 21 merumuskan kembali hubungan esensial antara anggota - anggota masyarakat.

Melalui norma hukum ditetapkan posisi masing - masing anggota masyarakat dalam hubungannya dengan pemenuhan suatu kebutuhan tertentu dan mengatur bagaimana keterkaitannya dengan posisi anggota masyarakat yang lain. Kehadiran hukum diharapkan dapat menimbulkan suatu kemantapan dan keteraturan dalam menyelenggarakan kebutuhan - kebutuhan seluruh anggota masyarakat.

Hukum pada umumnya diartikan sebagai keseluruhan peraturan atau kaedah dalam kehidupan bersama keseluruhan tentang tingkah laku yang berlaku dalam suatu kehidupan bersama yang dapat dipaksakan pelaksanaannya dengan suatu sanksi42. Proklamasi kemerdekaan Indonesia tanggal 17 Agustus 1945 adalah tonggak sejarah kemerdekaan Negara Indonesia lepas dari belenggu penjajahan. Pernyataan kemerdekaan ini secara tegas dinyatakan dalam Pembukaan Undang undang Dasar (UUD) 1945 alenia ke-3 yang berbunyi :“Atas berkat rahmat Allah Yang Maha Kuasa dan dengan didorongkan oleh keinginan luhur, supaya berkehidupan kebangsaan yang bebas maka rakyat Indonesia menyatakan dengan ini kemerdekaannya “.

Penyataan ini mengandung amanat dan bermakna bahwa bangsa Indonesia dalam melaksanakan kehidupan berbangsa, bernegara

42 Sudikno Mertokusumo, Mengenal Hukum, Suatu Pengantar, Yogyakarta: Liberti, 1986, hlman 37 
dan bermasyarakat adalah bebas sebagai suatu bangsa yang merdeka. Hal tersebut diatas tidak terlepas dari tujuan politik hukum di Indonesia sebagaimana dinyatakan dalam alenia ke-4 Pembukaan UUD 1945 terdapat cita - cita Negara Indonesia ,yaitu :

1. Untuk melindungi segenap bangsa dan seluruh tumpah darah Indonesia.

2. Untuk memajukan kesejahteraan umum,

3. Mencerdaskan kehidupan bangsa, dan

4. Ikut memelihara ketertiban dunia.

\section{Pembahasan}

Batasan/pengertian perlindungan dalam Undang-undang No.13 tahun 2006 disebutkan sebagai segala upaya pemenuhan hak dan pemberian bantuan untuk memberikan rasa aman kepada saksi dan/atau korban yang wajib dilaksanakan oleh Lembaga Perlindungan Saksi dan Korban atau lembaga lainnya.43

Pada awal abad XXI ini, dunia pendidikan di Indonesia menghadapi 3 (tiga) tantangan besar. Tantangan pertama,sebagai akibat dari krisis ekonomi, dunia pendidikan dituntut untuk dapat mempertahankan hasil-hasil pembangunan pendidikan yang telah dicapai. Kedua, untuk mengantisispasi era globalisas dunia pendidikan dituntut untuk mempersiapkan sumber daya

$43 \quad$ Undang-Undang No.13 Tahun 2006 tentang Perlindungan Saksi dan Korban manusia yang kompeten agar mampu bersaing dalam pasar kerja global. Ketiga, sejalan dengan diberlakukannya otonomi daerah, dunia pendidikan dituntut untuk melakukan perubahan dan penyesuaian sehingga dapat mewujudkan proses pendidikan yang lebih demokratis, memperhatikan keberagaman kebutuhan, keadaan daerah dan peserta didik, serta mendorong peningkatan partisipasi masyarakat

Pasal 39 ayat (2), Undang-undang Nomor 20 Tahun 2003 tentang Sistem Pendidikan Nasional menyebutkan bahwa tugas utama seorang Guru adalah dalam proses pembelajaran, pembimbingan dan pelatihan; sedangkan untuk pendidik pada perguruan tinggi diperluas dengan tugas di bidang penelitian dan pengabdian masyarakat.44

Korban kejahatan yang pada dasarnya merupakan pihak yang paling menderita dalam suatu tindak pidana, justru tidak memperoleh perlindungan sebanyak yang diberikan oleh Undang-Undang kepada pelaku kejahatan sebagaimana dikemukakan oleh Andi Hamzah: "Dalam membahas hukum acara pidana khususnya yang berkaitan dengan hak- hak asasi manusia, ada kecenderungan untuk mengupas hal-hal yang berkaitan dengan hak-hak tersangka tanpa memperhatikan pula hak-hak korban. 45

$44 \quad$ Siswanto S. Viktimologi dalam Sistem Peradilan Pidana, Sinar Grafika. 2012. Hlmn 42. 45 Andi Hamzah, Perlindungan HakHak Asasi Manusia dalam Kitab UndangUndang Hukum Acara Pidana,Bandung: Binacipta, 1986, Hal 33 
Demikian mulianya tugas seorang guru, sehingga menyebabkan profesi guru tersebut patut dilindungi dari setiap bentuk perbuatan menyimpang (kejahatan) yang dapat menjatuhkan harkat dan martabat profesi guru khususnya, dan pendidikan pada umumnya. Perlindungan profesi guru dapat ditinjau dari dua sudut pandang, yaitu 46

1. Perlindungan profesi guru dalam arti sempit, yakni perlindungan individual terhadap guru di dalam menjalankan profesinya, yang meliputi

a. Perlindungan dari perbuatan/tindakan yang dilakukannya dalam menjalankan tugas profesinya (subjek), dan;

b. Perlindungan profesi guru dari perbuatan dan tindakan orang lain (objek).

2. Perlindungan profesi guru dalam arti luas, yang diartikan sebagai perlindungan profesional/ fungsional/institusional, karena tujuannya adalah agar profesi guru atau institusi pendidikan dapat berjalan/ berfungsi dengan sebaik-baiknya sehingga kualitas pendidikan

dapat terus dipelihara dan ditingkatkan dalam encapai tujuan pendidikan nasional dan tujuan pembangunan nasional pada umumnya.

Bertolak dari itu pendekatan kebijakan itu pula, Sudarto berpendapat bahwa dalam mengahadapi masalah sentral yang pertama di atas, yang sering disebut masalah kriminalisasi,

46 Barda Nawawi Arief, Makalah "Perlindungan Profesi Guru Dari Aspek Hukum Pidana", disampaikan pada Seminar Nasional Perlindungan dan Pembinaan Pro-fesi Guru di Era Otonomi Daerah, Hotel Pandanaran Sema-rang, 29 Juli 2004, hlm. 2 -3 harus diperhatikan hal - hal yang pada intinya sebagai berikut:47

a. Penggunaan hukum pidana harus memperhatikan tujuan pembangunan nasional, yaitu mewujudkan masyarakat adil dan makmur yang merata materil spiritual berdasarkan pancasila, sehubungan dengan ini maka (penggunaan) hukum pidana bertujuan untuk menanggulangi kejahatan dan mengadakan penganugerahan terhadap tindakan penanggulangan itu sendiri, demi kesejahteraan dan pengayoman masyarakat.

b. Perbuatan yang diusahakan untuk dicegah atau ditanggulangi dengan hukum pidana harus merupakan perbuatan yang tidak dikehendaki yaitu perbuatan yang mendatangkan kerugian (materil dan/atau spiritual) atas warga masyarakat.

c. Penggunaan hukum pidana harus ada pula memperhitungkan prinsip biaya dan hasil (cost and benefit principle).

d. Penggunaan hukum pidana harus pula memperhatikan kapasitas atau kemampuan daya kerja dari badan - badan penegak hukum, yaitu jangan sampai ada kelampauan beban tugas (overbelasting).

Pendekatan berorientasi pada kebijakan sosial terlihat pula dalam symposium pembaharuan hukum pidana pada bulan Agustus 1980 
di Semarang. Dalam salah satu laporannya dinyatakan antara lain: 48

Masalah kriminalisasi dan dekriminalisasi atas suatu perbuatan haruslah sesuai dengan politik criminal yang dianut oleh bangsa Indonesia, yaitu sejauh mana perbuatan tersebut bertentangan dengan nilai - nilai fundamental yang berlaku dalam masyarakat dan oleh masyarakat dianggap patut atau tidak patut dihukum dalam rangka menyelenggarakan kesejahteraan masyarakat.

Berdasarkan pasal 351 ayat (1) Kitab Undang - Undang Hukum Pidana 49tentang penganiayaan disebutkan bahwa :

"penganiayaan diancam dengan pidana penjara paling lama dua tahun delapan bulan atau pidana denda paling banyak empat ribu lima ratus rupiah.

Menurut Ridwan Halim, bentuk-bentuk penyimpangan yang biasanya terjadi dalam dunia pendidikan dapat berupa:50

1. Penekanan nilai prestasi murid dalam segala bentuk dan tujuan;

2. Berbagai bentuk pungutan liar (pungli);

3. Berbagai bentuk penipuan dan pengakuan palsu yang dilakukan oleh oknum yang tidak bertanggung jawab;

4. Pencurian karangan dalam bentuk apapun dalam jumlah berapa pun yang disertai dengan

48 Laporan Simposium Pembaharuan Hukum Pidana Nasional, 1980 di Semarang

49 Solahudin, Kitab Undang - Undang Hukum Pidana, Visimedia, 2007, hlman 116, 50 Ridwan Halim, Tindak Pidana Pendidikan Dalam Asas-Asas Hukum Pidana Indonesia, Ghalia Indo-nesia, Jakarta, 1986, hlm 32 - 46 penipuan dan pengakuan palsu (plagiat);

5. Perbagai bentuk pelaksanaan Pendidikan yang salah, baik yang disengaja maupun yang tidak disengaja;

6. Dan, sebagai tambahan adalah perbuatanperbuatan yang merupakan tindak pidana umum (seperti yang diatur dalam KUHP dan Undang-undang di luar KUHP) yang dilakukan terhadap guru.

Menurut Marc Ancel kebijakan kriminal (criminal policy) adalah suatu usaha yang rasional dari masyarakat dalam menanggulangi kejahatan.51Secara garis besar kebijakan kriminal ini dapat ditempuh melalui dua cara yaitu :52

1. UpayaPenal,merupakanupayapenanggulangan kejahatan yang lebih menitikberatkan pada upaya - upaya yang sifatnya repressive (penindasan/pemberantasan/penumpasan) dengan menggunakan sarana penal (hukum penal);

2. Upaya Non-Penal, merupakan upaya penanggulangan kejahatan yang lebih menitikberatkan pada upaya-upaya yang sifatnya preventif (pencegahan/penangkalan/ pengendalian) sebelum kejahatan tersebut terjadi. Sasaran utama dari kejahatan ini adalah menangani faktor-faktor kondusif penyebab terjadinya kejahatan.

51 Barda Nawawi Arief, Bunga Rampai Kebijakan Hukum Pidana, PT. Citra Aditya Abadi, Bandung, 2002, hlm.1

52 Ibid 
Menurut Hart,53 fungsi hukum pidana adalah untuk menjaga keteraturan dan kesusilaan umum serta melindungi warga Negara dari apa yang disebut asusila atau yang merugikan dan untuk memberikan perlindungan atas eksploitasi dari pihak lain, khususnya bagi mereka yang lemah karena masih muda, lemah fisik, pikiran atau pengalaman. Perbandingan jumlah penduduk dengan jumlah kasus yang terjadi di Kalimantan Barat terkait dengan penganiayaan terhadap Guru oleh Orangtua murid masih terbilang sedikit seperti yang disebutkan penulis dalam table dibawah ini.

Tabel. 3.1. Daftar Nama Korban Penganiayaan oleh Orang Tua Murid terhadap guru.

\begin{tabular}{|c|c|c|c|c|c|}
\hline No & Asal & Korban & J. Kelamin & Profesi & $\begin{array}{c}\text { Asal Se- } \\
\text { kolah }\end{array}$ \\
\hline 1 & $\begin{array}{c}\text { Kabupaten } \\
\text { Kubu Raya } \\
\text { Kecamatan } \\
\text { Terentang } \\
\text { Desa Radak } \\
\text { Baru }\end{array}$ & Jamlh & Prempuan & $\begin{array}{c}\text { Guru } \\
\text { SMPN }\end{array}$ & $\begin{array}{c}\text { SDN } 20 \\
\text { Radak baru } \\
\text { Kecamtan } \\
\text { Terentang }\end{array}$ \\
\hline 2 & $\begin{array}{c}\text { Kabupaten } \\
\text { Sintang } \\
\text { Kecamatan } \\
\text { Sintang Desa } \\
\text { Mengkurai }\end{array}$ & M.A.Sya & Laki -Laki & $\begin{array}{l}\text { Guru } \\
\text { SDN }\end{array}$ & $\begin{array}{c}\text { SDN } 14 \\
\text { Mengkurai } \\
\text { Kecamatan } \\
\text { Sintang }\end{array}$ \\
\hline
\end{tabular}

Sumber : Desember 2016

Tabel.3.2. Daftar nama Pelaku Penganiayaan Oleh Orang tua Murid terhadap Guru

\begin{tabular}{|c|c|c|c|c|l|}
\hline No & Asal & Tersangka & J. Kelamin & Pekerjaan & $\begin{array}{l}\text { Pendi- } \\
\text { dikan }\end{array}$ \\
\hline 1 & $\begin{array}{c}\text { Kabupaten } \\
\text { Kubu Raya } \\
\text { Kecamatan } \\
\text { Terentang } \\
\text { Desa Radak } \\
\text { Baru }\end{array}$ & $\begin{array}{c}\text { Spnno dan } \\
\text { Ek Stjo }\end{array}$ & Laki -Laki & Petani & $\begin{array}{l}\text { T a m a t } \\
\text { S M P } \\
\text { (Sekolah } \\
\text { Menengah } \\
\text { Pertama) }\end{array}$ \\
\hline 2 & $\begin{array}{c}\text { Kabupaten } \\
\text { Sintang } \\
\text { Kecamatan } \\
\text { Sintang } \\
\text { Desa } \\
\text { Mengkurai }\end{array}$ & $\begin{array}{c}\text { Ddi Sdi } \\
\text { dan Mydn }\end{array}$ & Laki - Laki & Petani & $\begin{array}{l}\text { Tamat SD } \\
\text { (Sekolah } \\
\text { Dasar) }\end{array}$ \\
& & & & & \\
\hline
\end{tabular}

53 Edy O.S. Hiariej, Prinsip - Prinsip Hu-kum Pidana, Cahaya Atma Pustaka. Yogyakarta. 2016. Hlma .34
Sumber : Desember 2016

Dari jumlah kasus yang terjadi di Dua Kabupaten diatas masih cukup rendah tingkat kriminalitasnya apabila kita bandingkan dengan jumlah penduduk Kalimantan Barat kurang lebih 3.000.000 ( Tiga Juta Jiwa ). Berdasakan data diatas bukan berarti kita hanya menutup mata bahwa tidak akan ada lagi kasus penganiayaan yang dilakukan oleh orang tua murid kepada guru. Agar guru - guru di Kalimantan Barat khususnya dan Di Indonesia umumnya tidak merasa takut dalam melakukan kegiatan proses belajar - mengajar baik dalam mendidik dan memberikan pelatihan yang bersifat fisik kepada para siswa.

Menurut Ketua PGRI bahwa guru sudah dilindungi oleh undang - undang Guru dan Dosen, tetapi perlindungan yang diberikan masih belum cukup khususnya perlindungan dibidang hukum. Sehingga para orang tua murid berani untuk melakukan tindakan kejahatan yang brutal kepada setiap guru yang dianggap telah melakukan tindakan kepada anaknya.

A. Upaya Penanggulangan Penganiayaan terhadap Guru Oleh Orang tua Murid

Berdasarkan hasil wawancara yang dilakukan oleh penulis dengan guru bahwa mereka hanya biasanya melakukan upaya penanggulangan berbagaibentukperilakumenyimpangdalamdunia Pendidikan melalui jalur penal (menggunakan sarana hukum pidana) selama ini masih bersifat pragmatis. Artinya, ketentuan-ketentuan yang digunakan dalam rangka menanggulangi 
penyimpangan dalam dunia Pendidikan masih terbatas pada ketentuan pidana yang diatur dalam Kitab Undang-Undang Hukum Pidana, Undang-undang Sistem Pendidikan Nasional dan Undang-undang Perlindungan Anak.

Apabilaguruterkenamasalahhukumkhususnya yang berkaitan dengan tugasnya sebagai guru dia seolah harus berjuang sendiri. Undang-undang Nomor 14 Tahun 2005 tentang Guru dan Dosen pasal 7 ayat (1) huruf h mengamanatkan bahwa guru harus memilik jaminan perlindungan hukum dalam melaksanakan tugas keprofesionalan. Selanjutnya pada pasal 39 secara rinci dinyatakan:

(1) Pemerintah, pemerintah daerah, masyarakat, organisasi profesi, dan/atau satuan pendidikan wajib memberikan perlindungan terhadap guru dalam pelaksanaan tugas. (2) Perlindungan sebagaimana dimaksud pada ayat (1) meliputi perlindungan hukum, perlindungan profesi, serta perlindungan keselamatan dan kesehatan kerja.

(3) Perlindungan hukum sebagaimana dimaksud pada ayat (2) mencakup perlindungan hukum terhadap tindak kekerasan, ancaman, perlakuan diskriminatif, intimidasi, atau perlakuan tidak adil dari pihak peserta didik, orang tua peserta didik, masyarakat, birokrasi, atau pihak lain. (4) Perlindungan profesi sebagaimana dimaksud pada ayat (2) mencakup perlindungan terhadap pemutusan hubungan kerja yang tidak sesuai dengan peraturan perundangundangan, pemberian imbalan yang tidak wajar, pembatasan dalam menyampaikan pandangan, pelecehan terhadap profesi, dan pembatasan/pelarangan lain yang dapat menghambat guru dalam melaksanakan tugas. (5) Perlindungan keselamatan dan kesehatan kerja sebagaimana dimaksud pada ayat (2) mencakup perlindungan terhadap risiko gangguan keamanan kerja, kecelakaan kerja, kebakaran pada waktu kerja, bencana alam, kesehatan lingkungan kerja, dan/atau risiko lain. Berdasarkan kepada hal tersebut di atas, perlindungan bagi guru merupakan hal yang mutlak. Tetapi sayangnya, banyak guru yang bekerja dalam ketidakpastian baik berkaitan dengan status kepegawaiannya, kesejahteraannya, pengembangan profesinya, atau pun advokasi hukum ketika terkena masalah hukum.

Berdasarkan hasil wawancara yang dilakukan penulis dengan guru yang menjadi korban penganiayaan mengatakan bahwa dalam penyelesaian kasus tersebut pihak pelaku yaitu orang tua murid meminta untuk dilakukan mediasi yang dihadiri oleh kepala sekolah, komite sekolah, dan Pengurus Persatuan Guru Republik Indonesia (PGRI). Pelaku berharap mediasi untuk membatalkan proses hukum kasus penganiayaan tersebut dengan catatan bahwa pelaku akan melakukan surat pernyataan yang disaksikan oleh seluruh masyarakat dan berbagai pihak untuk tidak mengulangi lagi kesalahan tersebut.

Berdasarkan hasil wawancara Penulis dengan Ketua PGRI Kabupaten Kubu Raya bahwa perlindungan yang diberikan oleh lembaga tempat seluruh Guru di Indonesia 
dengan melakukan perlindungan yang bersifat fisik dan mental. Perlindungan yang bersifat fisik tersebut meliputi meminta kepada pihak berwenang untuk melakukan penahanan terhadap pelaku tindak pidana penganiayaan terhadap guru tersebut. Perlindungan yang bersifat mental dengan memberikan semangat dan motivasi kepada Guru yang menjadi koban penganiayaan oleh orang tua muridnya agar guru tersebut bisa menjalankan kewajiban sebagai tenaga pengajar dan pendidik seperti biasanya.

Perlindungan hukum tersebut berupa konsultasi hukum, mediasi, dan pemenuhan dan pemulihan hak pendidik dan tenaga kependidikan. Berdasarkan hasil wawancara yang dilakukan penulis terhadap pihak korban bahwa pernah melakukan konsultasi hukum bersama Persatuan Guru Republik Indonesia (PGRI) yang merupakan lembaga profesi sebuah organisasi Guru di republik ini. Hasil dari konsultasi hukum yang dilakukan bersama Pengurus Persatuan Guru Republik Indonesia (PGRI) menyimpulkan berbagai kesimpulan terkait kasus yang dialami oleh korban, diantaranya mengusulkan agar kasus tersebut diselesaikan secara kekeluargaan selain itu meminta kepada guru yang bersangkutan untuk mengadukan kepada pihak kepolisian agar pelaku tersebut dapat ditahan untuk memberikan perlindungan sementara kepada korban. Berdasarkan hasil wawancara yang dilakukan oleh penulis dengan Guru yang menjadi korban dari penganiayaan oleh bahwa mereka sangat mengharapkan diterbitkan Kebijakan pemerintah menetapkan agar dimuat dalam sebuah Undang-Undang yang pada intinya dapat melindungi mereka sebagai guru dalam menjalankan pekerjaannya sewaktu berada di dalam kelas maupun di luar kelas.

Pernyataan tersebut dibenarkan oleh Ketua PGRI cabang Sintang bahwa Undang - Undang Nomor 14 Tahun 2005 tentang Guru dan Dosen memberikan perlindungan hukum terhadap guru dalam menjalankan tugas profesionalnya masih belum maksimal dapat diterapkan dengan baik oleh seluruh komponen yang berkaitan dengan dunia pendidikan.

Berdasarkan hasil wawancara yang dilakukan oleh penulis dengan Kepala Kepolisian Resort Sintang (Kapolres Sintang ) bahwa Undang - Undang telah memberikan penanggulangan penganiayaan terhadap Guru oleh orangtua murid. Upaya penanggulangan yang diberikan oleh Kepolisian meliputi pencegahan sebelum dilakukan tindak pidana dan sesudah penganiayaan. Menurut pihak Kepolisian yang diwawancarai oleh penulis bahwa mereka 
hanya melakukan sosialisasi ke sekolah sekolah tentang pentingnya ketertiban dan ketentraman serta kenyamanan bagi guru dan peserta didik sewaktu mendapatkan pengajaran di bangku sekolah.

Berdasarkan hasil wawancara dengan Guru yang diwawancarai oleh penulis bahwa setiap akan memasuki tahun ajaran baru dilaksanakan sosialisasi tentang pentingnya ketertiban dan ketentraman serta kenyamanan bagi guru dan peserta didik sewaktu mendapatkan pengajaran di bangku sekolah. Berdasarkan hasil wawancara dengan pihak Kepolisian bahwa tidak hanya tahap pencegahan dengan sosialisasi di sekolah tentang pentingnya pendidikan yang bermartabat dan berkarakter melainkan juga dilakukan tindakan penindakan upaya hukum terkait dengan para orang tua murid,

Organisasi profesi guru dalam kepengurusannya nampaknya perlu melengkapi kepengurusannya dengan personel yang tugasnya melakukan advokasi hukum. Dan guru pun perlu didorong untuk menjadi anggota profesi guru supaya ketika ada masalah, dia bisa meminta bantuan kepada induk organisasinya untuk melakukan pendampingan atau bantuan hukum. Guru adalah pendidik profesional dengan tugas utama mendidik, mengajar, membimbing, mengarahkan, melatih, menilai, dan mengevaluasi peserta didik pada pendidikan anak usia dini jalur pendidikan formal, pendidikan dasar, dan pendidikan menengah.
Berdasarkan hasil wawancara yang dilakukan penulis dengan saudara korban bahwa terdapat beberapa bentuk perlindungan yang diberikan dari beberapa pihak seperti pihak kepolisian dengan menangkap dan menahan pelaku penganiayaan, pengadilan mengadili dan menjatuhkan pidan penjara kepada pelaku, selanjutnya perlindungan hukum yang diberikan oleh Organisasi profesi kepada korban seperti Persatuan Guru Republik Indonesia (PGRI) melaporkan pelaku penganiayaan kepada yang berwewenang ( kepolisian) untuk menindak lanjuti kasus penganiayaan tersebut.

Bentuk perlindungan yang diberikan oleh pihak kepolisian, Pengadilan, dan Lembaga Persatuan Guru Republik Indonesia (PGRI) bersifat permanen selama peraturan perundang - undangan mengaturnya masih berlaku. Bentuk perlindungan tersebut diantaranya berupa perlindungan fisik dan mental dari kekerasaan dan intervensi terhadap guru yang sedang dalam menjalankan tugas serta tidak terdapat perlindungan berupa penggantian sesuatu barang yang bersifat materi.

Menurut korban bahwa perlu adanya undang - undang tentang perlindungan terhadap guru untuk menjamin pekerjaan dan profesionalitas seseorang guru dalam melaksanakan proses belajar dan mengajar di sekolah baik dalam hal mendidik dan mentransper ilmu kepada anak didiknya. Sangat disayangkan apabila pekerjaan guru dalam mendidik dan 
mengajar di kelas terdapat campuran tangan dari orang tua murid yang tidak bertanggung jawab sehingga kedepannya pendidikan di Indonesia ini akan mengalami kehancuran karena ada berapa banyak kepala orang tua murid yang saling berbenturan kepentingan dalam mengharapkan anak - anaknya seperti keinginan individu orang tua tersebut.

Saat ini belum penulis temukan formulasi hukum yang mengatur sebagaimana baiknya perlindungan hukum apabila terjadi pada guru. Korban merasa pemerintah pusat dan pemerintah daerah harus mengambil bagian dalam memberikan jaminan keselamatan bagi guru dalam melaksakan profesi, secara hukum, dalam melanjutkan karir, dan jaminan hal intelektual dari guru. Perangkat hukum perundang - undangan yang berlaku saat ini baik Undang - Undang guru dan dosen dan peraturan perundangan lainnya masih belum mampu memberikan jaminan keselamatan bagi guru baik itu menyangkut masalah hukum yang dialaminya, karir, profesi, dan hak intelektualnya.

Upayadalammenanggulangipenganiayaan terhadap guru oleh orang tua murid yang kami lakukan tentu diarahkan atau difokuskan pada pembinaan dan pencegahan kepada para orang tua murid melalui sosialisasi mengenai tata tertib sekolah kepada para orang tua murid karakter. Hal ini dilakukan dalam bentuk program yang berkelanjutan. Program ini terintegrasi ke dalam program tahunan sekolah bidang kesiswaan.
Disamping itu juga dilakukan kegiatan layanan bimbingan dan konseling khususnya bagi siswa yang memiliki kasus atau permasalahan tertentu. Kegiatan layanan bimbingan dan konseling ini dilakukan oleh guru BP/BK baik pada siswa/klien secara individu (perorangan) maupun kelompok. Secara teknis program pendidikan karakter ini dikoordinir oleh guru PKn (pendidikan kewarganegaraan).

$$
\text { Munculnya berbagai bentuk }
$$
penganiayaan terhadap guru oleh orangtua murid yang dilakukan di tingkat sekolah dasar tersebut tentu ada faktor penyebabnya. Faktor-faktor penyebab penganiayaan terhadap guru oleh orangtua perlu diungkap secara jelas sehingga memudahkan dalam pembinaan dan pencegahannya. Dalam hubungan ini perlu dilakukan penelusuran informasi terutama pada Kepala Sekolah, orangtua murid, serta siswa yang bermasalah terkait dengan tindakan penganiayaan terhadap guru oleh orangtua murid di sekolah.

Selain itu perangkat hukum yang ada saat ini sudah cukup kuat untuk memberikan perlindungan hukum terhadap Guru seperti pasal 212, pasal 213, pasal 214, dan pasal 215 Kitab Undang - Undang Hukum Pidana (KUHP) tentang perlindungan Pegawai Negeri yang menjalankan tugas dan Peraturan Pemerintah Nomor 74 tahun 2008 tentang perlindungan terhadap profesi Guru pasal 39, pasal 40, dan pasal 41 .

Dengan demikian para guru juga harus mematuhi dengan baik yang sudah tercantum 
dalam tata tertib di sekolah tersebut sehingga tidak semau hatinya untuk melakukan tindakan fisik seperti memotong rambut siswa yang gondrong dan menampar siswa yang terlambat. Oleh sebab itu para guru dan orangtua siswa harus bersepakat akan apa yang sudah disepakati dalam tata tertib dari pihak sekolah karena tata tertib tersebut merupakan wujud nyata dari sekolah dan orangtua agar tidak ada tindakan sewenang

- wewenang yang semau hati para guru dalam memberikan sanksi kepada para orangtua siswa. Tata tertib tersebut bermanfaat untuk menjaga siswa dari tindakan dari Guru kepada muridnya, sehingga dapat disimpulkan para orang tua murid tidak perlu untuk melakukan penganiayaan kepada guru. Karena lebih baik para orang tua murid melakukan koordinasi dan komunikasi dengan para dewan guru dan komite sekolah apabila terjadinya sedikit penyimpangan yang memungkinkan akan membuat hubungan dari seluruh pihak menjadi tidak baik.

Berdasarkan hasil wawancara penulis dengan Ketua Persatuan Guru Republik Indonesia (PGRI) di sebuah Kabupaten yang terjadi penganiayaan oleh orang tua siswa kepada gurunya bahwa terjadi kurangnya informasi antara guru dan orang tua murid sehingga terjadi penganiayaan oleh orang tua murid terhadap guru. Kurangnya koordinasi dan komunikasi tersebut menurut penulis perlu dibentuk sebuah forum diskusi yang baik antara guru dan orang tua murid dalam rangka menyamakan pendapat dan harapan agar anak - anak bangsa ini menjadi cerdas seperti anak - anak bangsa lain yang cukup pintar dan cerdas dalam segala bidang. Faktor yang membuat orang tua murid melakukan tindak pidana penganiayaan kepada guru karena kuranya informasi dan koordinasi dari pihak sekolah dan komite sekolah . pembinaan dan perhatian pemerintah daerah terhadap perlindungan hukum kepada guru sangat minim.

Faktor yang membuat pelaku (orang tua Murid) melakukan penganiayaan kepada Guru disebabkan oleh kurangnya sosialisasi dan koordinasi antara pihak sekolah dengan pihak orang tua murid. Kurangnya sosialisasi dan koordinasi tersebut membuat pelaku ( Orang tua murid ) marah dan emosi sehingga berpikir untuk melakukan penganiayaan kepada guru. Kurangnya informasi yang akurat sehingga membuat para orang tua salah paham dengan perlakuan guru kepada anak - anak mereka sewaktu di sekolah yang menyebabkan para orang tua mulai emosi dan melakukan penganiayaan seperti pemukulan dan menggunting rambut guru.

Apabila penulis dapat simpulkan bahwa penganiayaan yang dilakukan oleh para orang tua murid kepada guru dikarenakan kurangnya koordinasi dan komunikasi antara para guru dengan para orang tua murid. Oleh sebab itu sebaiknya menurut penulis apabila para guru ingin memberikan hukuman maupun sanksi terhadap pelanggaran yang dilakukan oleh siswa - siswanya sebaiknya dikonsultasikan dulu 
kepada komite sekolah, kepala sekolah dan para orang tua. Walaupun demikian pada prinsipnya guru diberikan hak untuk mendidik dan membina siswa - siswanya menjadi lebih sebaik yang berarti guru harus memberikan sanksi apabila siswa tersebut melanggar peraturan sekolah. Tetapi pada kesempatan yang sama pula guru harus memmpertimbangkan sanksi seperti apa yang sebaiknya diberikan kepada siswa.

Berdasarkan hasil wawancara penulis dengan Kepala Sekolah SDN (Sekolah Dasar Negeri ) nomor 20 Radak Baru Kecamatan Terentang Kabupaten Kubu Raya bahwa masyarakat kita lebih cepat tersulut emosinya apabila terdapat keluarganya yang menjadi korban tindakan dari para gurunya walapun tindakan para gurunya tidak lebih untuk mendidik si anak agar menjadi manusia yang cerdas. Pergeseran budaya dan mental masyarakat tersebut merupakan akibat dari modernisasi dan globalisasi yang semakin cepat tanpa ruang dan waktu misalnya saja hari ini setiap anak sudah bermain telpon seluluer dengan fitur game yang mengasikkan sehingga membuat para anak menjadi susah dididik oeh para orang tua apalagi dididik oleh guru di Sekolah.

Pernyataan tersebut di benarkan oleh Kepala Sekolah Dasar Negeri Nomor 14 Mengkurai Kecamatan Sintang bahwa para orang tua terlalu mempercayakan anak - anaknya atau lebih dimanja sehingga tindakan dari si guru untuk mendidik anaknya tidak dipikirkan apalagi apabila manusianya emosi. Mental masyarakat tersebut harus diperbaiki secepatnya untuk memperbaiki sikap dan tindakan para orang tua yang seringkali melakukan penganiayaan kepada para guru. Sebaiknya para orangtua harus diberikan pemahaman dan pengertian terhadap tindakan yang akan dilakukan oleh para guru terkait pendisiplinan siswa. Sehingga tindakan para guru tidak membuat para orang tua melakukan tindakan kekerasan kepada para guru yang memiliki niat yang cukup mulia untuk mencerdaskan kehidupan bangsa.

\section{B.Kebijakan Hukum Pidana Untuk melindungi}

Profesi guru untuk Sekarang dan untuk masa yang akan datang dari tindakan penganiayaan. Berdasarkan Dalam Undang - Undang Nomor 05 Tahun 2015 Tentang Guru dan Dosen dan dijabarkan dalam Peraturan Pemrintah nomor 74 Tentang Guru disebutkan bahwa Guru berhak mendapatkan perlindungan dalam melaksanakan tugas dalam bentuk rasa aman dan jaminan keselamatan dari Pemerintah, Pemerintah Daerah, satuan pendidikan, Organisasi Profesi Guru, dan/ atau Masyarakat sesuai dengan kewenangan masing-masing. Rasa aman dan jaminan keselamatan dalam melaksanakan tugas sebagaimana dimaksud pada ayat (1) diperoleh Guru melalui perlindungan:a. hukum; b. profesi; dan c. keselamatan dan kesehatan kerja. d. Masyarakat, Organisasi Profesi 
Guru, Pemerintah atau Pemerintah Daerah dapat saling membantu dalam memberikan perlindungan.

Apabila guru terkena masalah hukum khususnya yang berkaitan dengan tugasnya sebagai guru dia seolah harus berjuang sendiri. Undang-undang Nomor 14 Tahun 2005 tentang Guru dan Dosen pasal 7 ayat (1) huruf $h$ mengamanatkan bahwa guru harus memilik jaminan perlindungan hukum dalam melaksanakan tugas keprofesionalan. Selanjutnya pada pasal 39 secara rinci dinyatakan: (1) Pemerintah, pemerintah daerah, masyarakat, organisasi profesi, dan/atau satuan pendidikan wajib memberikan perlindungan terhadap guru dalam pelaksanaan tugas. (2) Perlindungan sebagaimana dimaksud pada ayat (1) meliputi perlindungan hukum, perlindungan profesi, serta perlindungan keselamatan dan kesehatan kerja.

(3) Perlindungan hukum sebagaimana dimaksud pada ayat (2) mencakup perlindungan hukum terhadap tindak kekerasan, ancaman, perlakuan diskriminatif, intimidasi, atau perlakuan tidak adil dari pihak peserta didik, orang tua peserta didik, masyarakat, birokrasi, atau pihak lain. (4) Perlindungan profesi sebagaimana dimaksud pada ayat (2) mencakup perlindungan terhadap pemutusan hubungan kerja yang tidak sesuai dengan peraturan perundangundangan, pemberian imbalan yang tidak wajar, pembatasan dalam menyampaikan pandangan, pelecehan terhadap profesi, dan pembatasan/pelarangan lain yang dapat menghambat guru dalam melaksanakan tugas. (5) Perlindungan keselamatan dan kesehatan kerja sebagaimana dimaksud pada ayat (2) mencakup perlindungan terhadap risiko gangguan keamanan kerja, kecelakaan kerja, kebakaran pada waktu kerja, bencana alam, kesehatan lingkungan kerja, dan/atau risiko lain. Berdasarkan kepada hal tersebut di atas, perlindungan bagi guru merupakan hal yang mutlak.

\section{Simpulan}

Faktor yang membuat pelaku (orang tua Murid) melakukan penganiayaan kepada Guru disebabkan oleh kurangnya sosialisasi dan koordinasi antara pihak sekolah dengan pihak orang tua murid. Kurangnya sosialisasi dan koordinasi tersebut membuat pelaku ( Orang tua murid ) marah dan emosi sehingga berpikir untuk melakukan penganiayaan kepada guru. Kurangnya informasi yang akurat sehingga membuat para orang tua salah paham dengan perlakuan guru kepada anak - anak mereka sewaktu di sekolah yang menyebabkan para orang tua mulai emosi dan melakukan penganiayaan seperti pemukulan dan menggunting rambut guru.

Kebijakan Hukum Pidana untuk melindungi profesi Guru untuk sekarang dan untuk masa yang akan datang 
dari tindakan penganiayaan. Kepolisian melakukan tindakan penyelidikan dan penyidikan sesuai dengan ketentuan perundang - undangan yang berlaku. Pihak kepolisian akan menahan pelaku demi kepentingan hukum untuk memberikan perlindungan kepada korban.Pengadilan akan mengadili pelaku untuk memberikan rasa keadilan bagi korban sesuai dengan peraturan perundang - undangan yang berlaku.

Persatuan Guru Republik Indonesia (PGRI) akan memberikan pendampingan baik secara psikologis dan hukum kepada korban agar kondisi korban dapat kembali pulih untuk melaksanakan kegiatan belajar mengajar seperti biasa di Sekolah asalnya. Melaporkan kepada yang berwewenang ( Aparat kepolisian ) untuk menindaklanjuti kasus penganiayaan tersebut. Selain itu juga menyelesaikan permasalahan dengan cara kekeluargaan tanpa diajukan ke pihak kepolisian.

\section{DAFTAR PUSTAKA}

Andi Hamzah, Perlindungan Hak-Hak Asasi Manusia dalam Kitab Undang-Undang Hukum Acara Pidana,Bandung: Binacipta, 1986.
Krimonologi, Rafika Aditama,2007.

Bacharudin Musthafa, Education Reform (The Case of Indonesia), The Republic of Indonesia and The World Bank, Jakarta, 2001.

Barda Nawawi Arief, Bunga Rampai Kebijakan Hukum Pidana, PT. Citra Aditya Abadi, Bandung, 2002.

Barda Nawawi Arief, Beberapa Aspek Kebijakan Penegakan dan Pengembangan Hukum Pidana Edisi Revisi, Citra Aditya Bakti, Bandung, 2005.

Dikdik. M. Arief Mansur, Urgensi Perlidungan Korban Kejahatan Antara Norma dan Realita,Jakarta: PT. RajaGrafindo Persada, 2007.

Edy O.S. Hiariej, Prinsip - Prinsip Hukum Pidana, Cahaya Atma Pustaka. Yogyakarta. 2016.

Esmi Warassih, Pranata Hukum Sebuah Telaah Sosiologis, Pustaka Magister Semarang, 2014.

Halim, Ridwan, Tindak Pidana Pendidikan

Dalam Asas-Asas Hukum Pidana

Indonesia, Ghalia Indonesia, Jakarta, 1986.

R. Soesilo, Kitab Undang-Undang Hukum Pidana (KUHP) Serta KomentarKomentarnya Lengkap Pasal Demi Pasal, Bogor: Politeia, 1991.

S. Siswanto, Viktomologi dalam Sistem Peradilan Pidana, Jakarta, 2012.

Sudikno Mertokusumo, Mengenal Hukum, Suatu Pengantar, Yogyakarta: Liberti, 1986. 
Sudarto, Hukum dan Hukum Pidana, Bandung, 1981,

\section{Peraturan Perundang - Undangan}

Undang-Undang Dasar Republik Indonesia 1945.

Undang-Undang Nomor. 13 Tahun 2006 Tentang Perlindungan Saksi Dan Korban

Undang - Undang nomor 15 Tahun 2005 Tentang Guru dan Dosen.

Kitab Undang - Undang Hukum Pidana, Solahudin, Visimedia, 2007.

Peraturan Pemerintah Nomor 74 Tahun 2008

Tentang Guru dan Dosen

Peraturan Menteri Pendidikan dan Kebudayaan

Republik Indonesia Nomor 10 Tahun 2017

Tentang perlindungan Bagi Pendidik dan

Tenaga Kependidikan. 